\begin{tabular}{|l|l|l||}
\hline \multicolumn{2}{|c|}{ PublisherInfo } \\
\hline \hline PublisherName & $:$ & BioMed Central \\
\hline \hline PublisherLocation & $:$ & London \\
\hline \hline PublisherImprintName & $:$ & BioMed Central \\
\hline \hline
\end{tabular}

\title{
ATS Critical Care Assembly
}

\begin{tabular}{||l|l|l||}
\hline \multicolumn{2}{|c||}{ ArticleInfo } \\
\hline \hline ArticleID & $:$ & 4285 \\
\hline \hline ArticleDOI & $:$ & $10.1186 /$ ccf-2000-webreport1543 \\
\hline \hline ArticleCitationID & $:$ & webreport1543 \\
\hline \hline ArticleSequenceNumber & $:$ & 26 \\
\hline \hline ArticleCategory & $:$ & Web report \\
\hline ArticleFirstPage & $:$ & 1 \\
\hline \hline ArticleLastPage & $:$ & 3 \\
\hline \hline & $:$ & RegistrationDate : 2000-5-5 \\
ArticleHistory & $:$ & OnlineDate \\
\hline \hline ArticleCopyright & $:$ & Current Science Ltd2000-5-5 \\
\hline \hline ArticleGrants & $:$ & \\
\hline \hline ArticleContext & $:$ & 1305444 \\
\hline \hline
\end{tabular}




\section{Overview}

This website is a sub-section of the American Thoracic Society (ATS) website. Its role is to 'inform ATS members of the activities of the Critical Care Assembly, and to provide a venue for the exchange of information to physicians and allied health professionals who care for critically ill patients'.

\section{Description}

At the moment this site has five 'departments' with others likely to be added as part of their ongoing site development process. There is assembly information containing details of the various committees, assembly activities and a list of the ATS assembly membership (only viewable by ATS members). There is also a section devoted to upcoming critical care meetings. Whilst this section is not unique amongst critical care websites, the information is presented in a novel manner. As well as the standard list format, the meetings can also be viewed as a calendar (similar in look to those seen in a number of personal information managers). Within the calendar, additional information on the various meetings can be found by clicking on the relevant link.

The Journal Club covers 10 categories, each overseen by a different editor. One paper per month is reviewed in each category. Currently, most of the categories have reviews for either February or March. Each category is archived, with reviews available back to 1998.

The Educational Resources section is split into two sections, General Critical Care and the Pulmonary Artery Catheter Education Program. The General Critical Care section has a monthly case presentation. Five questions (and their answers) accompany the case. The Pulmonary Artery Catheter Education Program is only available to ATS members.

The section devoted to patient educational materials is excellent. This is a didactic and very comprehensive source of basic information about the workings of an ICU. The general procedural information would be of use to any intensivist looking for a concise, but informative, explanation to give to patients/relatives. The legal material is designed around the needs of US patients and is probably of less value to the international community.

\section{Evaluation}


The site looks very plain and is very text dense. There is no reliance on flashy graphics, and almost no use of colour. The emphasis is very much on the dissemination of information. The navigation system is quite idiosyncratic. Instead of the usual buttons, or text links, individual parts of the site are reached by pull down menus. This does take some getting used to.

In all, this site is very worthy of a visit. Its simplicity ensures that it is very fast to load, and there is a large amount of material to view.

\section{Evaluation}

No special requirements. Certain sections are only available to ATS members.

\section{References}

1. ATS Assembly on Critical Care. [http://www.thoracic.org/assemblies/cc/cc.html] 